\title{
Use of Polymers/ Waste Rubber in Road Network Development in Uttarakhand State
}

\author{
Kamal Kumar ${ }^{1}$, Anand Singh ${ }^{1}$ S K Maity ${ }^{1}$ Sandeep Negi ${ }^{2}$ \\ ${ }^{I}$ (CSIR-Indian Institute of Petroleum, India) \\ ${ }^{2}(S G R R(P G)$ Collegel HNB GU, India)
}

\begin{abstract}
Proper utilization of industrial polymer/waste tyre rubber are a major threat to environment specially in developing countries where poverty, population and lack of proper waste management have catalyzed this problem. Use of waste polymer like waste tyres in road construction has potential for utilization and disposal these waste polymers instead of non-environment friendly methods like burning and landfills. In this paper we have highlighted the use of polymeric material in scientific as well as eco-friendly point of new. The main focus of this paper is to review and discuss the feasibility for using polymer modified bitumen (PMB) for developing high performance road network in uttarakhand. The experimental results reported in this paper are taken from the test sections of polymer modified bituminous (PMB) road laid at delhi-yamanotri marg near Herbertpur under a joint project of Indian Institute Of Petroleum (CSIR-IIP) and central road research institute (CRRI). This polymer modified bituminous road in the state is first of its kind. Three commercially available modified binders crumb rubber modifier (CRM) styrene-butadiene-styrene (SBS) and ethylene butyl acrylate (EBA) were used for construction of test sections; which were compared for their performance. Various physical tests like elastic recovery, softening point, penetration, viscosity and fail temperatures were carried out on modified binders and post construction evaluation tests like unevenness index measurement and Benkelman Beam Deflection tests were carried out on test sections. The results show the improvement in engineering properties like marshall stability, retained stability of road compared to unmodified bituminous road in terms of traffic and weather conditions of Uttarakhand. The findings of this research can serve as the base for the use of other wastes from the industries in roads making technology on which the research is already in progress at CSIR-Indian Institute of Petroleum and CSIR-Central Road Research Institute.
\end{abstract}

Keywords: CRMB, Ethyl Butyl Acetate, Polymer Modified Bitumen, Rheology, Styrene Butediene Styrene

\section{Introduction}

Bitumen is a visco-elastic material composed of asphaltene and maltene. Asphaltene is the dispersed phase and maltene is the dispersion medium. Conventional and modified binders are used to make flexible pavements. Air blowing of base bitumen is one of the most common approach used to make conventional bitumen $^{(1-2)}$. This approach has some limitations like high temperature susceptibility and energy consuming process. The other approaches to make bitumens are addition of polymers and addition of additives. In some cases blending of fluxing components is also followed.

Various polymer modifiers based on nature (elastomer, plastomer and reclaimed tyre of crumb) are used for making perpetual pavements ${ }^{(3)}$. The main aim of bitumen modification through polymers is to combine high cohesive strength at elevated temperature with elasticity at low temperature ${ }^{(4)}$. There are various accured benefits in the polymer modification of bitumen. Increase in the cost of polymer modified bitumens is offset by the enhanced useful life span of road surfacing. The capability of polymer modifiers is to resist the degradation of bitumen at mixing temperature.

In this paper different polymer modifiers are used to make polymer modified bitumen as per guidelines of Indian Road Congress (IRC). The base bitumen 60/70 grade is high temperature susceptible; when mixed with polymer modifiers, converted into polymer modified bitumens of low temperature susceptibility. The polymer modified bitumen offers low temperature susceptibility and high performance on pavements. Polymer modified bitumen pavements have high load bearing capacity because they have high value of fail temperatures. This results increase of life span of roads over roads made of conventional bitumen.

\subsection{Materials and Methods}

\section{Experimental}

60/70 grade base bitumen used in the study was supplied by cpcl chennai. Three types of polymer modifiers were used in the study. These polymers were styrene butadiene styrene (SBS), ethyl butyl acrylate (EBA) and crumb rubber (CR). SBS is an elastomeric polymers supplied by LG polymers, EBA is a plastomeric polymers supplied by Dupont Polymers, and cr from waste tyres from local market. Finnawax (fw) and gilsonite additives were supplied by CPCL Chennai. 


\subsection{Physico-Chemical Characterization of Base Bitumen}

Physico-Chemical Characterization Of Base Bitumen Was Carried Out As Per BIS/ASTM Test Procedures. The Base Bitumen (60/70) Were Characterized For Penetration, Softening Point, Ductility, Flash Point, Matter Soluble In Trichloroethylene, Viscosity At $60^{\circ} \mathrm{C}$, and Viscosity at $135^{\circ} \mathrm{C}$ etc. As Per BIS/ASTM test Procedures. Three Types Of Polymer Modifiers Were Used In The Study. The Physico-Chemical Characteristics of 60/70 grade base bitumen used in the study as base feed stock is shown in Table - 1

Table: 1 Characteristics of Base Feed Stock 60/70 Grade Bitumen

\begin{tabular}{|c|c|c|}
\hline S.No & Characteristics & 60/70 Grade Bitumen \\
\hline 1. & Density, $\mathrm{d}_{4}{ }^{15}$ & 1.0477 \\
\hline 2 & Water Content, \%Wt & 0.1 \\
\hline 3. & 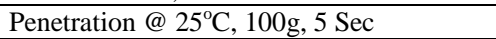 & 67 \\
\hline 4. & Softening Point, ${ }^{\circ} \mathrm{C}$ & 48.5 \\
\hline 5. & Penetration Ratio & 32.83 \\
\hline 6. & Ductility@ $@ 2{ }^{\circ} \mathrm{C}, \mathrm{Cms}$ & +100 \\
\hline 7. & Flash Point, ${ }^{\circ} \mathrm{C}$ & 226 \\
\hline 8. & Matter Soluble In Trichloroethylene, \%Wt & $>99.0$ \\
\hline 9. & Viscosity @ $60^{\circ} \mathrm{C}$, Poise & 2457.9 \\
\hline 10. & Viscosity@135 ${ }^{\circ} \mathrm{C}, \mathrm{cSt}$ & 511.3 \\
\hline 11. & \multicolumn{2}{|c|}{ Rolling Thin Film Oven Test (RTFOT) } \\
\hline a. & Loss in , \%Wt & $<1.0$ \\
\hline b. & Retained Penetration, $\%$ Of Original & 67.2 \\
\hline
\end{tabular}

\subsection{Preparation of Polymer Modified Bitumen From Base Bitumen}

Polymer modification of base bitumen was carried out in $500 \mathrm{ml}$ glass assembly to optimize the polymer dosages, reaction time and temperature. The operating temperature for the digestion of polymers had been in the ranging of $170 / 180^{\circ} \mathrm{c}$ and homogenization is carried out for 1.2 to 2.0 hours at constant stirring rate of 250-300 rpm. All the three polymers were used in the varying concentration levels i.e. SBS (3.0 to $5.0 \% \mathrm{wt}$ ), EBA (2.5 to $4.5 \% \mathrm{wt}$ ) and CR (10 to $16 \% \mathrm{wt}$ ) with base bitumen (60/70 bitumen).

The physico-chemical characterization of modified bitumen containing varying percentage of crumb rubber $(\mathrm{CR})$ is shown in table 2.

Table 2 Physico-Chemical Characteristics of Modified Bitumen Containing Varying \% Of Cr

\begin{tabular}{|c|c|c|c|c|}
\hline Characteristics & \multicolumn{4}{|c|}{ CR \% Wt } \\
\hline 60/70 Grade Bitumen & 10 & 12 & 14 & 16 \\
\hline Penetration@ $@ 25^{\circ} \mathrm{C}, 100 \mathrm{~g}, 5 \mathrm{Sec}, \mathrm{Dmm}$ & 56 & 55 & 56 & 54 \\
\hline Softening Point, ${ }^{\circ} \mathrm{C}$ & 52 & 52 & 55 & 54 \\
\hline Elastic Recovery Of Half Thread In Ductilometer @ $15^{\circ} \mathrm{C}, \%$ & 60 & 60 & - & 76 \\
\hline Flash Point, ${ }^{\circ} \mathrm{C}$ & $>220$ & $>220$ & $>220$ & $>220$ \\
\hline Matter Soluble In Trichloroethylene, \%Wt & $>99.00$ & $>99.00$ & $>99.00$ & $>99.00$ \\
\hline Separation Difference In Softening Point, ${ }^{\circ} \mathrm{C}$ & - & - & - & 3.0 \\
\hline \multicolumn{5}{|c|}{ Rolling Thin Film Oven Test (RTFOT) } \\
\hline Penetration@ @ 25 $\mathrm{C}, 100 \mathrm{~g}, 5 \mathrm{Sec}, \%$ Of Original & 83.9 & 81.8 & 78.6 & 77.8 \\
\hline Increase In Softening Point, ${ }^{\circ} \mathrm{C}$ & 1.0 & 1.5 & 1.0 & 6.0 \\
\hline Elastic Recovery Of Half Thread In Ductilometer @ $25{ }^{\circ} \mathrm{C}, \%$ & 55.00 & 60.00 & & 69.00 \\
\hline
\end{tabular}

The physico-chemical characterization of $10 \%$ wt CR modified bitumen containing $1.0 \%$ wt of styrene butadiene styrene (SBS) co-polymer is shown in table 3. This bitumen is designated as CRMB 55.

Table 3 Physico-Chemical Characteristics of Modified Bitumen Containing 10\% CR With 1\% SBS

\begin{tabular}{|c|c|c|}
\hline S.No & Characteristics & CRMB 55 \\
\hline 1. & Penetration@ $25^{\circ} \mathrm{C}, 100 \mathrm{~g}, 5 \mathrm{Sec}, \mathrm{Dmm}$ & 46 \\
\hline 2. & Softening Point, ${ }^{\circ} \mathrm{C}$ & 58 \\
\hline 3. & Ductility @ $27^{\circ} \mathrm{C}, \mathrm{Cms}$ & - \\
\hline 4. & Flash Point, ${ }^{\circ} \mathrm{C}$ & $>220$ \\
\hline 5. & Elastic recovery of half thread in ductilometer @ $15^{\circ} \mathrm{C}, \%$ & 79 \\
\hline 7. & Separation difference in softening point, ${ }^{\circ} \mathrm{C}$ & 3.0 \\
\hline 8. & \multicolumn{2}{|c|}{ Rolling Thin Film Oven Test (RTFOT) } \\
\hline a. & 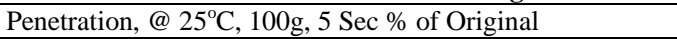 & 88.2 \\
\hline b. & Increase in softening point, ${ }^{\circ} \mathrm{C}$ & 4.0 \\
\hline c. & Elastic recovery of half thread in ductilometer @ $25^{\circ} \mathrm{C}, \%$ & 72.0 \\
\hline
\end{tabular}

In similar manner the physico-chemical characterization of modified bitumen containing varying percentage of styrene butadiene styrene (SBS) co-polymer is shown in table 4. 
Table 4 Physico-Chemical Characteristics of Modified Bitumen Containing Varying \% of SBS

\begin{tabular}{|l|l|l|l|l|}
\hline Characteristics & \multicolumn{4}{|c|}{ SBS \% Wt } \\
\hline $60 / 70$ grade bitumen & 3.0 & 3.5 & 4.0 & 5.0 \\
\hline Penetration @ $25^{\circ} \mathrm{C}, 100 \mathrm{~g}, 5 \mathrm{Sec}, \mathrm{dmm}$ & 37 & 39 & 40 & 40 \\
\hline Softening point, ${ }^{\circ} \mathrm{C}$ & 60 & 60.5 & 61.5 & - \\
\hline Ductility @ $27^{\circ} \mathrm{C}, \mathrm{cms}$ & +75 & +75 & +75 & +75 \\
\hline Elastic recovery of half thread in ductilometer @ $15^{\circ} \mathrm{C}, \%$ & 74 & 85 & 80 & - \\
\hline
\end{tabular}

The physico-chemical characterization of $3.5 \%$ wt SBS modified bitumen containing $1.0 \%$ wt of gilsonite is shown in table 5 . This bitumen is termed as elastomeric polymer modified bitumen and is designated as PMB-70 (E). Gilsonite is used as an additive to improve the softening point and penetration of bituminous binder.

Table 5 Physico-Chemical Characteristics Of 3.5\% Sbs With $1.0 \%$ Gilsonite

\begin{tabular}{|l|l|c|}
\hline S.No & Characteristics & PMB-70 (E) \\
\hline 1. & Penetration @ 25 ${ }^{\circ} \mathrm{C}, 100 \mathrm{~g}, 5 \mathrm{Sec}, \mathrm{dmm}$ & 52 \\
\hline 2. & Softening point, ${ }^{\circ} \mathrm{C}$ & 58 \\
\hline 3. & Ductility @ 27 ${ }^{\circ} \mathrm{C}, \mathrm{cms}$ & +75 \\
\hline 4. & Flash point, ${ }^{\circ} \mathrm{C}$ & $>220$ \\
\hline 5. & Elastic recovery of half thread in ductilometer @ $15^{\circ} \mathrm{C}, \%$ & 80 \\
\hline 7. & Separation difference in softening point, ${ }^{\circ} \mathrm{C}$ & 2.0 \\
\hline 8. & \multicolumn{1}{|c|}{ Rolling Thin Film Oven Test (RTFOT) } \\
\hline a. & Loss In \%Wt & $<1.0$ \\
\hline b. & Reduction in penetration of residue @ $25^{\circ} \mathrm{c}, \%$ & 34.0 \\
\hline c. & Increase in softening point, ${ }^{\circ} \mathrm{C}$ & 2.0 \\
\hline d. & Elastic recovery of half thread in ductilometer @ $25^{\circ} \mathrm{C}, \%$ & 86.0 \\
\hline
\end{tabular}

In similar manner the physico-chemical characterization of modified bitumen containing varying percentage of ethyl butyl acrylate (EBA) is shown in table 6.

Table 6 Physico-Chemical Characteristics of Modified Bitumen Containing Varying \% of EBA

\begin{tabular}{|l|c|c|c|c|}
\hline Characteristics & \multicolumn{3}{|c|}{ EBA \% Wt } \\
\hline 60/70 grade bitumen & 2.5 & 3.0 & 3.5 & 4.5 \\
\hline Penetration @ $25^{\circ} \mathrm{C}, 100 \mathrm{~g}, 5 \mathrm{Sec}, \mathrm{dmm}$ & 35 & 30 & 33 & 31 \\
\hline Softening point, ${ }^{\circ} \mathrm{C}$ & 54 & 57 & 59.5 & 60 \\
\hline Ductility @ $27^{\circ} \mathrm{C}, \mathrm{cms}$ & +75 & +75 & +75 & +75 \\
\hline Elastic recovery of half thread in ductilometer @ $15^{\circ} \mathrm{C}, \%$ & 74 & 78 & 85 & 80 \\
\hline
\end{tabular}

The physico-chemical characterization of $3.5 \%$ wt EBA modified bitumen containing $1.5 \%$ wt of finnawax is shown in table 7. This bitumen is termed as plastomeric polymer modified bitumen and is designated as pmb-70 (P). Finnawax is also used as an additive to improve the softening point and penetration of bituminous binder.

Table 7 Physico-Chemical Characteristics Of 3.5\% EBA With 1.5 \% FW

\begin{tabular}{|c|c|c|}
\hline S.No & Characteristics & Pmb-70 (P) \\
\hline 1. & Penetration@ $25^{\circ} \mathrm{C}, 100 \mathrm{~g}, 5 \mathrm{Sec}$ & 59 \\
\hline 2. & Softening point, ${ }^{\circ} \mathrm{C}$ & 56.0 \\
\hline 3. & Ductility @ $27^{\circ} \mathrm{C}, \mathrm{cms}$ & 58.0 \\
\hline 4. & Flash point, ${ }^{\circ} \mathrm{C}$ & $>220$ \\
\hline 5. & Elastic recovery of half thread in ductilometer @ $15{ }^{\circ} \mathrm{C}, \%$ & 58 \\
\hline 7. & Separation difference in softening point, ${ }^{\circ} \mathrm{C}$ & 1.5 \\
\hline 8. & \multicolumn{2}{|c|}{ Rolling Thin Film Oven Test (RTFOT) } \\
\hline a. & Loss in, \%Wt & $<1.0$ \\
\hline b. & Reduction in penetration of residue @ $25^{\circ} \mathrm{C}, \%$ & 30.3 \\
\hline c. & Increase in softening point, ${ }^{\circ} \mathrm{C}$ & 4.5 \\
\hline $\mathrm{d}$. & Elastic recovery of half thread in ductilometer @ $25{ }^{\circ} \mathrm{C}, \%$ & 60.0 \\
\hline
\end{tabular}

\subsection{Rheological Studies of Polymer Modified Bitumen}

AR 1500ex Rheometer was used to DSR study of polymer modified bituminous samples. The fail temperatures of the three polymer modified bitumen were determined after rolling thin film oven test (RTFOT) and pressure ageing vessel test (PAV) test. RTFOT gives the ageing of bituminous binder during laying and compaction of pavements where as PAV test simulated the ageing during service period of 3 or 5 years etc. The 
fail temperatures of un-aged and aged bitumen of CRMB-55, PMB-70 (E) and PMB-70 (P) were reported in Table 8 .

Table 8 Rheological Characteristics of Base Bitumen and PMBs

\begin{tabular}{|c|c|c|c|c|c|}
\hline \multirow{2}{*}{ Bitumen } & \multicolumn{3}{|c|}{ Fail Temperature, ${ }^{\circ} \mathrm{C}$} & \multirow{2}{*}{$\begin{array}{c}\text { Elastic Recovery, } 15^{\circ} \mathrm{C}, \% \\
\text { Separation Difference, } \\
\text { (Degree) }\end{array}$} \\
\cline { 2 - 5 } & Original Binder & RTFO & PAVT & & \\
\hline $60 / 70$ & 65.9 & 60.7 & 13.0 & & - \\
\hline CRMB-55 & 63.5 & 60.3 & 13.5 & & 3.0 \\
\hline PMB-70 (E) & 66.2 & 65.1 & 15.1 & 79 & 2.0 \\
\hline PMB-70 (P) & 69.8 & 66.5 & 18.5 & 58 & 1.5 \\
\hline
\end{tabular}

\subsection{Bulk Preparation of Polymer Modified Bitumen from Base Bitumen}

All the three types of modified bitumens CRMB-55, PMB-70 (E) and PMB-70 (p) were prepared in bulk at Hindcol Chennai on the same conditions as established at lab scale at CSIR-IIP dehradun. Bitumen modified with all the three types of polymers was sealed and stored in containers leveling CRMB-55, PMB-70 (E) and PMB-70 (P). These containers then transported to CSIR-IIP Dehradun for construction of test sections in Uttarakhand state.

\subsection{Construction of Test Section}

Nearly $1.5 \mathrm{~km}$ long test section was constructed in the supervision of engineers of PWD uttarakhand and scientists of CSIR-IIP bitumen lab Dehradun at Herbertpur-Saharanpur state Highway (Dehli-Yamunotri Marg). Picture of constructed test section can be seen in Fig-1.

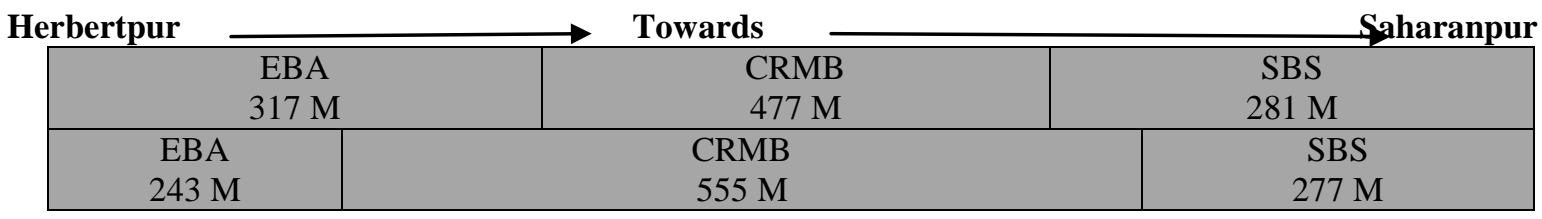

Fig.-1 Constructed test section near Herbertpur, Dehradun

After construction of test section, it was monitored by CSIR-CRRI, New-Delhi at regular interval of 4 or 5 months to check its performance. Different studies were carried on test sections during its periodic monitoring like deflection studies, Benkelman studies. The data are reported in Tables 9, 10 and 11.

Table 9 Performance Testing of Constructed Test Section

\begin{tabular}{|l|c|c|c|c|}
\hline Characteristics & $\begin{array}{c}\text { CRMB Modified } \\
\text { Mix }\end{array}$ & SBS Modified Mix & EBA Modified Mix & $\begin{array}{c}\text { Specified Limit as } \\
\text { per IRCSP 53:2002 }\end{array}$ \\
\hline Marshall Stability, kg & 1432 & 1280 & 1205 & 1200, Min \\
\hline Flow Value, mm & 3.5 & 2.9 & 3.2 & $3-5$ \\
\hline Retained Stability, \% & 91 & 93 & 94 & 90, Min \\
\hline Bulk Density, gm/cc & 2.381 & 2.362 & 2.364 & 2.27 \\
\hline
\end{tabular}

Table 10 Periodic Monitoring of Constructed Test Section

\begin{tabular}{|l|l|}
\hline \multicolumn{2}{|c|}{ Periodic Monitoring } \\
\hline Post Construction & June 2007 \\
\hline First Cycle & November 2007 \\
\hline Second Cycle & March 2008 \\
\hline Third Cycle & July 2008 \\
\hline Fourth Cycle & December 2008 \\
\hline Fifth Cycle & June 2009 \\
\hline Sixth Cycle & November 2009 \\
\hline Seventh Cycle & June 2010 \\
\hline
\end{tabular}

Table 11 Test Results of Benkelman Beam Studies Conducted On Test Sections

\begin{tabular}{|c|c|c|c|c|c|}
\hline \multirow{2}{*}{ Section } & \multirow{2}{*}{ Direction } & \multicolumn{4}{|c|}{ Average Deflection (Mm) } \\
\cline { 3 - 6 } & & June 2007 & June 2008 & June 2009 & May 2010 \\
\hline Sbs & Up & 0.59 & 0.55 & 0.92 & 1.01 \\
\hline & Down & 0.69 & 1.27 & 1.02 & 1.12 \\
\hline
\end{tabular}




\begin{tabular}{|c|c|c|c|c|c|}
\hline Crmb & Up & 0.56 & 0.54 & 1.21 & 1.32 \\
\hline & Down & 0.66 & 1.35 & 1.41 & 1.59 \\
\hline Eba & Up & 0.53 & 0.52 & 1.10 & 1.29 \\
\hline & Down & 0.64 & 1.40 & 1.49 & 1.53 \\
\hline
\end{tabular}

\section{Result And Discussion}

The physico-chemical characterization of $60 / 70$ base bitumen is indicated in table 1 . High density (1.0477) of base bitumen indicated that the base bitumen is aromatic rich. High solubility of base bitumen in trichloroethylene (>99.00\% wt) indicated that base bitumen is aromatic rich and it has no foreign material which will deteriorate its properties to make modified bitumen.

Increased concentration of $\mathrm{CR}$ from $10 \% \mathrm{wt}$ to $16 \% \mathrm{wt}$ in base bitumen; increased the softening point up-to some extent but decreased the penetration. Because after RTFOT; penetration at $25^{\circ} \mathrm{C}, \%$ of original was found maximum, in case modified with $10 \% \mathrm{wt} \mathrm{CR}$. This is one of the desirable properties for modification and hence $10 \% \mathrm{wt}$ concentration of CR is considered best for further modification. The properties of $10 \% \mathrm{wt}$ CR modified bitumen are further modified with $1 \%$ wt SBS. Maximum penetration, $\%$ of original after RTFOT indicated that modified bitumen did not deteriorate much during laying and compaction. This is further confirmed by the minimum change $\left(1^{\circ}\right)$ in softening point after RTFOT. When $10 \% \mathrm{wt}$ of crumb rubber is added to 60/70 grade base bitumen with $1 \%$ wt SBS, it meets all requirement of CRMB-55 bitumen. This bitumen is termed as CRMB-55.

Increased concentration of SBS from $3.0 \% \mathrm{wt}$ to $5.0 \% \mathrm{wt}$ in base bitumen; increased the penetration value from 37 to $40 \mathrm{dmm}$ and softening point is slightly increased from 60 to $61^{\circ} \mathrm{C}$. Maximum elastic recovery of half thread in ductilometer at $15^{\circ} \mathrm{C}$ is observed with $3.5 \%$ wt of SBS. This indicated that this is the suitable concentration of SBS to make modified bitumen. This is further supported by high softening point at high penetration at low concentration (3.5\%wt) of SBS. When base bitumen is mixed with $3.5 \%$ wt of SBS and 1.0 $\%$ wt of gilsonite; it meets all requirement of PMB-70 grade bitumen. This is elastomeric bitumen as SBS is an elastomer and is termed as PMB-70 (E).

Increased concentration of EBA from $2.5 \% \mathrm{wt}$ to $4.5 \% \mathrm{wt}$ in base bitumen; decreased the penetration value from 35 to $31 \mathrm{dmm}$ and increased the softening point from 54 to $60^{\circ} \mathrm{C}$. High softening point $59.5^{\circ} \mathrm{C}$ at high penetration $(33 \mathrm{dmm})$ indicated that it is the suitable concentration for further modification of bitumen. When base bitumen is mixed with $3.0 \%$ wt of EBA and $1.5 \%$ wt of FW; it meets all requirement of PMB-70 grade bitumen. This is plastomeric bitumen as EBA is a plastomer and is termed as PMB-70 (P).

Rheological analysis showed that the fail temperature of base bitumen was $65.9^{\circ} \mathrm{C}$. When base bitumen is modified with SBS or EBA; the fail temperature is increased to $66.2{ }^{\circ} \mathrm{C}$ and $69.8^{\circ} \mathrm{C}$ respectively. This is due to the formation of three dimensional network structures by polymers in modified bitumen. In case of CRMB-55 the fail temperature is decreased to $63.5^{\circ} \mathrm{C}$. This is due to increase in separation difference up-to 3.0 as rubber particle swelled in base bitumen. Due to elastomeric nature of SBS, it showed maximum elastic recovery (80.0 $\%$ ) of half thread in ductilometer test. (This data in indicated in table 10)

Marshall Stability of all the three modified bitumens was above $1200 \mathrm{~kg}$. This indicated that modified bitumens had better compaction with aggregates. The flow values were in the range of 2.9 to 3.5 as specified. (table 7). This indicated that modified bitumens were stripping resistant.

Visual observations and field performance data showed that the rating of the surface dressing base macadam concrete $(\mathrm{SDBC})$ in the following order (SBS>EBA $>\mathrm{CRMB})$. Rheological data also support this finding.

Data collected after one month of the laying of test section indicated less than $1 \mathrm{~mm}$ deflection on the entire test section. This indicated that test section was structurally sound.

\section{Figures And Tables}

Table 1 Characteristics of Base Feed Stock 60/70 Grade Bitumen

\begin{tabular}{|c|c|c|}
\hline S.No & Characteristics & 60/70 Grade Bitumen \\
\hline 1. & Density, $\mathrm{d}_{4}{ }^{15}$ & 1.0477 \\
\hline 2 & Water Content, \%wt & 0.1 \\
\hline 3. & Penetration@ $25^{\circ} \mathrm{C}, 100 \mathrm{~g}, 5 \mathrm{Sec}$ & 67 \\
\hline 4. & Softening point, ${ }^{\circ} \mathrm{C}$ & 48.5 \\
\hline 5. & Penetration Ratio & 32.83 \\
\hline 6. & Ductility@27 $97^{\circ} \mathrm{C}, \mathrm{cms}$ & +100 \\
\hline 7. & Flash point, ${ }^{\circ} \mathrm{C}$ & 226 \\
\hline 8. & Matter soluble in trichloroethylene, \%wt & $>99.0$ \\
\hline 9. & Viscosity @ $60^{\circ} \mathrm{C}$, Poise & 2457.9 \\
\hline 10. & Viscosity@135 ${ }^{\circ} \mathrm{C}, \mathrm{Cst}$ & 511.3 \\
\hline 11. & \multicolumn{2}{|c|}{ Rolling Thin Film Oven Test (RTFOT) } \\
\hline c. & Loss in, \%wt & $<1.0$ \\
\hline d. & Retained penetration, $\%$ of original & 67.2 \\
\hline
\end{tabular}


Table 2 Physico-Chemical Characteristics of Modified Bitumen Containing Varying \% of CR

\begin{tabular}{|c|c|c|c|c|}
\hline Characteristics & \multicolumn{4}{|c|}{$\mathrm{Cr} \% \mathrm{Wt}$} \\
\hline 60/70 Grade Bitumen & 10 & 12 & 14 & 16 \\
\hline Penetration@ $@ 25^{\circ} \mathrm{C}, 100 \mathrm{~g}, 5 \mathrm{Sec}, \mathrm{dmm}$ & 56 & 55 & 56 & 54 \\
\hline Softening point, ${ }^{\circ} \mathrm{C}$ & 52 & 52 & 55 & 54 \\
\hline Elastic recovery of half thread in ductilometer @ $15{ }^{\circ} \mathrm{C}, \%$ & 60 & 60 & - & 76 \\
\hline Flash Point, ${ }^{\mathrm{O}} \mathrm{C}$ & $>220$ & $>220$ & $>220$ & $>220$ \\
\hline Matter soluble in trichloroethylene, \%wt & $>99.00$ & $>99.00$ & $>99.00$ & $>99.00$ \\
\hline Separation difference in softening point, ${ }^{\circ} \mathrm{C}$ & - & - & - & 3.0 \\
\hline \multicolumn{5}{|c|}{ Rolling Thin Film Oven Test (RTFOT) } \\
\hline Penetration @ $25^{\circ} \mathrm{C}, 100 \mathrm{~g}, 5 \mathrm{Sec}, \%$ of original & 83.9 & 81.8 & 78.6 & 77.8 \\
\hline Increase in softening point, ${ }^{\circ} \mathrm{C}$ & 1.0 & 1.5 & 1.0 & 6.0 \\
\hline Elastic recovery of half thread in ductilometer @ $25^{\circ} \mathrm{C}, \%$ & 55.00 & 60.00 & 65.00 & 69.00 \\
\hline
\end{tabular}

Table 3 Physico-Chemical Characteristics of Modified Bitumen Containing 10\% CR With 1\% SBS

\begin{tabular}{|l|l|c|}
\hline S.No & Characteristics & CRMB 55 \\
\hline 1. & Penetration @ 25 ${ }^{\circ} \mathrm{C}, 100 \mathrm{~g}, 5 \mathrm{Sec}, \mathrm{dmm}$ & 46 \\
\hline 2. & Softening point, ${ }^{\circ} \mathrm{C}$ & 58 \\
\hline 3. & Ductility @ $27^{\circ} \mathrm{C}, \mathrm{cms}$ & - \\
\hline 4. & Flash point, ${ }^{\circ} \mathrm{C}$ & $>220$ \\
\hline 5. & Elastic recovery of half thread in ductilometer @ 15 ${ }^{\circ} \mathrm{C}, \%$ & 79 \\
\hline 7. & Separation difference in softening point, ${ }^{\circ} \mathrm{C}$ & 3.0 \\
\hline 8. & \multicolumn{1}{|c|}{ Rolling Thin Film Oven Test (RTFOT) } & 88.2 \\
\hline d. & Penetration, @ 25 ${ }^{\circ} \mathrm{C}, 100 \mathrm{~g}, 5 \mathrm{Sec} \%$ of original & 4.0 \\
\hline e. & Increase in softening point, ${ }^{\circ} \mathrm{C}$ & 72.0 \\
\hline f. & Elastic recovery of half thread in ductilometer @ 25 ${ }^{\circ} \mathrm{C}, \%$ & \\
\hline
\end{tabular}

Table 4 Physico-Chemical Characteristics of Modified Bitumen Containing Varying \% of SBS

\begin{tabular}{|l|l|l|l|l|}
\hline Characteristics & \multicolumn{4}{|c|}{ SBS \% Wt } \\
\hline $60 / 70$ Grade Bitumen & 3.0 & 3.5 & 4.0 & 5.0 \\
\hline Penetration @ $25^{\circ} \mathrm{C}, 100 \mathrm{~g}, 5 \mathrm{Sec}, \mathrm{dmm}$ & 37 & 39 & 40 & 40 \\
\hline Softening point, ${ }^{\circ} \mathrm{C}$ & 60 & 60.5 & 61.5 & - \\
\hline Ductility @ $27^{\circ} \mathrm{C}, \mathrm{cms}$ & +75 & +75 & +75 & +75 \\
\hline Elastic recovery of half thread in ductilometer @ $15^{\circ} \mathrm{C}, \%$ & 74 & 85 & 80 & - \\
\hline
\end{tabular}

Table 5 Physico-Chemical Characteristics Of 3.5\% SBS With 1.0 \% Gilsonite

\begin{tabular}{|l|l|c|}
\hline S.No & Characteristics & PMB-70 (E) \\
\hline 1. & Penetration @ 25 ${ }^{\circ} \mathrm{C}, 100 \mathrm{~g}, 5 \mathrm{Sec}, \mathrm{dmm}$ & 52 \\
\hline 2. & Softening Point, ${ }^{\circ} \mathrm{C}$ & 58 \\
\hline 3. & Ductility @ $27^{\circ} \mathrm{C}, \mathrm{cms}$ & +75 \\
\hline 4. & Flash Point, ${ }^{\circ} \mathrm{C}$ & $>220$ \\
\hline 5. & Elastic recovery of half thread in ductilometer @ $15^{\circ} \mathrm{C}, \%$ & 80 \\
\hline 7. & Separation difference in softening point, ${ }^{\circ} \mathrm{C}$ & 2.0 \\
\hline 8. & \multicolumn{1}{|c|}{ Rolling Thin Film Oven Test (RTFOT) } & $<1.0$ \\
\hline e. & Loss in, $\%$ wt & 34.0 \\
\hline f. & Reduction in penetrationof residue @ 25 ${ }^{\circ} \mathrm{C}, \%$ & 2.0 \\
\hline g. & Increase in softening point, ${ }^{\circ} \mathrm{C}$ & 86.0 \\
\hline h. & Elastic recovery of half thread in ductilometer @ 25 ${ }^{\circ} \mathrm{C}, \%$ & \\
\hline
\end{tabular}

Table 6 Physico-Chemical Characteristics of Modified Bitumen Containing Varying \% of EBA

\begin{tabular}{|l|c|c|c|c|}
\hline Characteristics & \multicolumn{4}{|c|}{ EBA \% Wt } \\
\hline $60 / 70$ grade bitumen & 2.5 & 3.0 & 3.5 & 4.5 \\
\hline Penetration @ $25^{\circ} \mathrm{C}, 100 \mathrm{~g}, 5 \mathrm{Sec}, \mathrm{dmm}$ & 35 & 30 & 33 & 31 \\
\hline Softening point, ${ }^{\circ} \mathrm{C}$ & 54 & 57 & 59.5 & 60 \\
\hline Ductility @ $27^{\circ} \mathrm{C}, \mathrm{cms}$ & +75 & +75 & +75 & +75 \\
\hline Elastic recovery of half thread in ductilometer @ $15^{\circ} \mathrm{C}, \%$ & 74 & 78 & 85 & 80 \\
\hline
\end{tabular}


Table 7 Physico-Chemical Characteristics of 3.5\% EBA With $1.5 \%$ FW

\begin{tabular}{|l|l|c|}
\hline S.No & Characteristics & Pmb-70 (P) \\
\hline 1. & Penetration @ 25 ${ }^{\circ} \mathrm{C}, 100 \mathrm{~g}, 5 \mathrm{Sec}$ & 59 \\
\hline 2. & Softening point, ${ }^{\circ} \mathrm{C}$ & 56.0 \\
\hline 3. & Ductility @ $27^{\circ} \mathrm{C}, \mathrm{cms}$ & 58.0 \\
\hline 4. & Flash point, ${ }^{\circ} \mathrm{C}$ & $>220$ \\
\hline 5. & Elastic recovery of half thread in ductilometer @ $15^{\mathrm{O}} \mathrm{C}, \%$ & 58 \\
\hline 7. & \multicolumn{1}{|c|}{ Rolling Thin Film Oven Test (RTFOT) } & 1.5 \\
\hline 8. & Separation difference in softening point ${ }^{\circ} \mathrm{C}$ & $<1.0$ \\
\hline e. & Loss in, \%wt & 30.3 \\
\hline f. & Reduction in penetration of residue @ 25 ${ }^{\circ} \mathrm{C}, \%$ & 4.5 \\
\hline g. & Increase in softening point, ${ }^{\circ} \mathrm{C}$ & 60.0 \\
\hline h. & Elastic recovery of half thread in ductilometer @ 25 ${ }^{\circ} \mathrm{C}, \%$ & \\
\hline
\end{tabular}

Table 8 Rheological Characteristics of Base Bitumen and PMBs

\begin{tabular}{|c|c|c|c|c|c|}
\hline \multirow{2}{*}{ Bitumen } & \multicolumn{2}{|c|}{ Fail Temperature, ${ }^{\circ} \mathrm{C}$} & Elastic Recovery, $15^{\circ} \mathrm{C}, \%$ & $\begin{array}{c}\text { Separation } \\
\text { Difference, } \\
\text { (Degree) }\end{array}$ \\
\cline { 2 - 4 } & Original Binder & RTFOT & PAVT & & - \\
\hline $60 / 70$ & 65.9 & 60.7 & 13.0 & - & 79 \\
\hline CRMB-55 & 63.5 & 60.3 & 13.5 & 80 & 3.0 \\
\hline PMB-70 (E) & 66.2 & 65.1 & 15.1 & 58 & 2.0 \\
\hline PMB-70 (P) & 69.8 & 66.5 & 18.5 & & 1.5 \\
\hline
\end{tabular}

Herbertpur

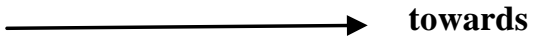

Saharanpur

\begin{tabular}{|c|c|c|}
\hline & $\begin{array}{l}\text { CRMB } \\
477 \mathrm{M}\end{array}$ & $\begin{array}{c}\text { SBS } \\
281 \mathrm{M}\end{array}$ \\
\hline $\begin{array}{c}\text { EBA } \\
243 \mathrm{M}\end{array}$ & $\begin{array}{l}\text { CRMB } \\
555 \mathrm{M}\end{array}$ & $\begin{array}{c}\text { SBS } \\
277 \mathrm{M}\end{array}$ \\
\hline
\end{tabular}

Fig. 1 Constructed Test Section near Herbertpur, Dehradun

Table 9 Performance Testing of Constructed Test Section

\begin{tabular}{|l|c|c|c|c|}
\hline Characteristics & $\begin{array}{c}\text { CRMB Modified } \\
\text { Mix }\end{array}$ & $\begin{array}{c}\text { SBS Modified } \\
\text { Mix }\end{array}$ & EBA Modified Mix & $\begin{array}{c}\text { Specified Limit As Per } \\
\text { IRCSP 53:2002 }\end{array}$ \\
\hline Marshall Stability, kg & 1432 & 1280 & 1205 & $1200, \mathrm{~min}$ \\
\hline Flow Value, mm & 3.5 & 2.9 & 3.2 & $3-5$ \\
\hline Retained Stability, \% & 91 & 93 & 94 & $90, \mathrm{~min}$ \\
\hline Bulk Density, gm/cc & 2.381 & 2.362 & 2.364 & 2.27 \\
\hline
\end{tabular}

Table 10 Periodic Monitoring of Constructed Test Section

\begin{tabular}{|l|l|}
\hline \multicolumn{2}{|c|}{ Periodic Monitoring } \\
\hline Post Construction & June 2007 \\
\hline First Cycle & November 2007 \\
\hline Second Cycle & March 2008 \\
\hline Third Cycle & July 2008 \\
\hline Fourth Cycle & December 2008 \\
\hline Fifth Cycle & June 2009 \\
\hline Sixth Cycle & November 2009 \\
\hline Seventh Cycle & June 2010 \\
\hline
\end{tabular}


Table 11 Test Results Of Benkelman Beam Studies Conducted On Test Sections

\begin{tabular}{|c|c|c|c|c|c|}
\hline \multirow{2}{*}{ Section } & \multirow{2}{*}{ Direction } & \multicolumn{4}{|c|}{ Average Deflection (mm) } \\
\cline { 3 - 6 } & & June 2007 & June 2008 & June 2009 & May 2010 \\
\hline SBS & Up & 0.59 & 0.55 & 0.92 & 1.01 \\
\hline & Down & 0.69 & 1.27 & 1.02 & 1.12 \\
\hline CRMB & Up & 0.56 & 0.54 & 1.21 & 1.32 \\
\hline & Down & 0.66 & 1.35 & 1.41 & 1.59 \\
\hline EBA & Up & 0.53 & 0.52 & 1.10 & 1.29 \\
\hline & Down & 0.64 & 1.40 & 1.49 & 1.53 \\
\hline
\end{tabular}

\section{Conclusion}

Based on result and discussion it can be concluded that prepared modified bitumens have fail temperatures greater than $60.0^{\circ} \mathrm{c}$. This is one of the desirable characteristic of modified bitumen. Among all the three modified bitumens; PMB-70 (E) as such and after RTFOT has maximum elastic recovery. This property results good performance of bitumen on road side. Visual observations and field performance data showed that the rating of the surface dressing base macadam concrete (SDBC) in the following order (SBS>EBA $>C R M B$ ). rheological data also support this finding.

\section{Acknowledgements}

I wish thank to the central road research institute, New Delhi and PWD Uttarakhand Dehradun for their valuable support. Authors thankful to Director CSIR-IIP to complete the study on polymer modified bitumen.

\section{References}

[1]. Read. John, Whiteoak, The Shell Bitumen Hand Book, Fifth Edition

[2]. Standard Test Method For Determining The Rheological Properties Of Asphalt Binder Using A Dynamic Shear Rheometer (ASTM D7175).

[3]. Kumar Praveen, Mehndiratta.H.C, Singh.K,, Lakshmanp.O. Bishop, Rheological Properties Of Crumb Rubber Modified Bitumen A Lab Study, Journal Of Scientific \& Industrial Reseah, 2009, 812-816

[4]. Burger A.F, Jenkins.K.J, Muller.J, Vande.M.F.C ,Rheology Of Polymer Modified Bitumen, Proc. 20 ${ }^{\text {th }}$ South African Transport Conference 'Meeting The Transport Challenge In South Africa' South Africa, 2001, 16-20 